\title{
Age and Gender Dependent Amino Acid Concentrations in the Feather, Feather-Free and Whole Empty Body Protein of Fast Growing Meat-Type Chickens
}

\author{
Christian Wecke, Daulat Rehman Khan, Angela Sünder, Frank Liebert \\ Division Animal Nutrition Physiology, Department of Animal Sciences, Georg-August-University of Göttingen, Göttingen, \\ Germany \\ Email: flieber@gwdg.de
}

How to cite this paper: Wecke, C., Khan, D.R., Sünder, A. and Liebert, F. (2018) Age and Gender Dependent Amino Acid Concentrations in the Feather, Feather-Free and Whole Empty Body Protein of Fast Growing Meat-Type Chickens. Open Journal of Animal Sciences, 8, 223-238. https://doi.org/10.4236/ojas.2018.83017

Received: March 28, 2018

Accepted: July 1, 2018

Published: July 4, 2018

Copyright $\odot 2018$ by authors and Scientific Research Publishing Inc. This work is licensed under the Creative Commons Attribution International License (CC BY 4.0).

http://creativecommons.org/licenses/by/4.0/

\begin{abstract}
Two consecutive growth experiments with meat-type chickens (Ross 308) were conducted in order to quantify the age-dependent amino acid (AA) content in the whole body protein of male and female birds based on experimental data of the feather and feather-free body protein fractions. Birds were reared under uniform housing and feeding conditions (floor pens, 15 pens per gender, 5 birds per pen) during the starter (day 1 to 22) and grower period (day 22 to 36). Both the starter and grower diet based on corn, wheat, soybean meal, soybean protein concentrate and feed amino acids was formulated to ensure an equal feed protein quality close to the ideal amino acid ratio by adjusting a constant mixture of the feed proteins. At start of the experiment and further on weekly up to the end of the $5^{\text {th }}$ week, 15 birds per gender (each 3 pens of 5 birds) were selected and fasted for $24 \mathrm{~h}$, to emptying of gastro-intestinal tract, respectively. Subsequently, birds were euthanized and the feathers were manually removed. Nitrogen $(\mathrm{N})$ and AA content were determined both in the feather and feather-free body fraction. The concentration of individual AAs in both of body protein fraction is varying considerably. Explicitly higher Cys, Ser and Pro but importantly lower Met, Lys and His concentrations were found in the feather protein. Furthermore, significant differences $(p<0.001)$ for nearly all AAs of the studied body protein fractions and the whole empty body protein dependent on age of birds were observed. Especially high deviations were obtained during the first week of age and at the end of the experiment. According to this observed variation of AA concentrations must be concluded that the body AA composition of meat-type chickens during growth is not constant. The detected gender-specific differ-
\end{abstract}


ences for several AAs in the feather and body protein of male and female birds were rather low and with very low variation.

\section{Keywords}

Growing Chickens, Feather Amino Acids, Body Amino Acids, Age, Gender

\section{Introduction}

Body composition data of modern fast growing meat-type broiler chickens provide important information for further optimization of nutrient supply. However, the database for amino acid (AA) content of whole body and body fractions like feathers of current genotypes is scarce. Furthermore, different assumptions exist regarding the age and gender dependent body AA composition. Several studies supposed a rather uniform AA content of the whole body protein of broiler chickens during growth [1] [2] [3] [4] [5]. In consequence, constant AA contents in feather and feather-free body protein were applied as reference data for assessing AA requirement data [6] [7]. However, this assumption is invalid according to influencing factors like genotype [8] [9] [10], gender [11] [12] and age [11] [13]-[18]. Specifically, an age-dependent change of the whole body protein AA composition can be expected due to different allometric growth rates of individual body tissues and organs [7] [19] [20] [21]. Additionally, the dietary protein and AA supply can also impact on body AA composition [9] [10] [15] [22]-[27]. An increased accuracy in estimations of the adequate dietary AA supply could be achieved if substantial body protein fractions are initially investigated separately.

Therefore, in addition to our experimental data including both the age and gender dependent proportions of the feather and feather-free body fraction including their protein partitioning [28] [29], the present study aimed to provide detailed results about the AA composition of the whole body protein based on weekly analyses of feather and feather-free body fractions from male and female meat-type chickens during the entire growing period up to market weight.

\section{Materials and Methods}

Both growth experiments utilized a total of 180 growing broiler chickens (male to female birds $=1: 1$ ) were conducted at the facilities of the Division Animal Nutrition Physiology, Department of Animal Sciences at Georg-August-University Göttingen and were approved by the Lower Saxony Federal Office for Consumer Protection and Food Safety (LAVES), Germany.

\subsection{Animals and Housing}

Freshly hatched meat-type chickens (ROSS 308) were obtained from a commercial hatchery and placed together in a floor pen on wood shavings. At next day 
(d1) averaged weighed birds were randomly allotted to 15 pens per gender (each 5 birds per pen) and kept under uniform management and feeding conditions (starter period: 1 to $22 \mathrm{~d}$; grower period: 22 to $36 \mathrm{~d}$ ). Further details were already reported elsewhere [28].

\subsection{Diets and Feeding}

Both starter and grower diets [28] were based on corn, wheat and soybean meal, soybean protein concentrate and crystalline feed AAs as main ingredients. Diet formulation aimed to meet current recommendations and was adjusted close to the ideal dietary AA ratios [30]. A constant mixture of the protein sources yielded equal feed protein quality during both of the feeding periods.

\subsection{Collection and Sampling}

At start of the experiment and weekly up to the end of the 5th week, 15 male and 15 female chickens ( 3 pens per week and gender) were placed separately with free access to drinking water. Selected birds were fasted for 24 hours for emptying the digestive tract to yield an "empty body mass". According to animal welfare regulations, these birds were subsequently euthanized by $\mathrm{CO}_{2}$ inhalation. Each sample of quantitatively collected feathers and of feather-free empty body was separately stored in plastic bags at $-20^{\circ} \mathrm{C}$ for further processing as previously described in detail [28].

\subsection{Chemical Analyses}

Feed ingredients, diets, feathers and feather-free empty bodies were analysed in duplicates according to the German standard procedures [31]. $\mathrm{N}$ analyses were conducted by DUMAS-method (LECO ${ }^{\circledR}$ TruMac, LECO Instrument GmbH, Kirchheim, Germany) and crude protein $(\mathrm{CP})$ was calculated by factor as $\mathrm{N} \times$ 6.25 [31] [32]. AA composition of the feed protein sources, feathers and feather-free bodies was analysed by ion-exchange chromatography (Biochrom ${ }^{\circledR}$ 30, Biochrom Ltd. Cambridge, England) following acid hydrolysis without and with application of an oxidation step for quantitative determination of sulphur containing AAs [32]. Tryptophan (Trp) was quantified by ion-exchange chromatography (LC 300, Biotronik, Eppendorf-Netheler-Hinz GmbH, Hamburg, Germany) following hydrolysis with lithium hydroxide based on the modified method 4.11.2 according to [31].

\subsection{Statistical Analyses}

Statistical analyses run with SPSS software package (Version 23.0 for Windows; IBM SPSS Statistics Inc., Chicago, IL, USA). Two-way analysis of variance (ANOVA) was performed to compare means of variables depending both on age and gender of broiler chickens as main effects, inclusive their interactions. Verification of variance homogeneity was evaluated by Levene-test. Significant differences $(p \leq 0.05)$ were identified by Games-Howell test and Tukey post-hoc test, respectively. 


\section{Results}

The age and gender dependent data for development of feather and feather-free body mass were already reported [28] and further applied for the current calculations. Table 1 summarizes $\mathrm{N}$ and AA contents in the feather protein depending on age and gender, respectively. Generally, high $\mathrm{N}$ contents significantly influenced by age of birds $(p<0.001)$ were observed in the dry matter (DM) of feathers. Accordingly, the feather $\mathrm{N}$ content was significantly reduced from day old to $15 \mathrm{~d}$ old chickens, but with further increasing of age the $\mathrm{N}$ concentrations in the feather $\mathrm{N}$ tends to increase again. However, no gender-specific effect on feather $\mathrm{N}$ content was found and no interaction occurred between age and gender.

Feathers contain rather high quantities of the dispensable AAs glutamic acid (Glu), serine (Ser) and proline (Pro). Among indispensable AAs, specificly high concentrations of leucine (Leu), arginine (Arg) and cysteine (Cys) are located in the feather protein fraction. Otherwise, feathers contain a very low quantity of methionine (Met). For all AAs age-dependent effects $(p<0.001)$ were identified in feathers of male and female birds, except for glycine (Gly). The contents of lysine (Lys), Met, Cys and Glu initially increased up to respective near to the end of the starter period and afterwards declined up to slaughter weight. In contrast,

Table 1. Content of $\mathrm{N}$ (\% of dry matter) and amino acids $(\mathrm{g} / 16 \mathrm{~g} \mathrm{~N})$ in feathers of broiler chickens depending on age and gender. ${ }^{1}$

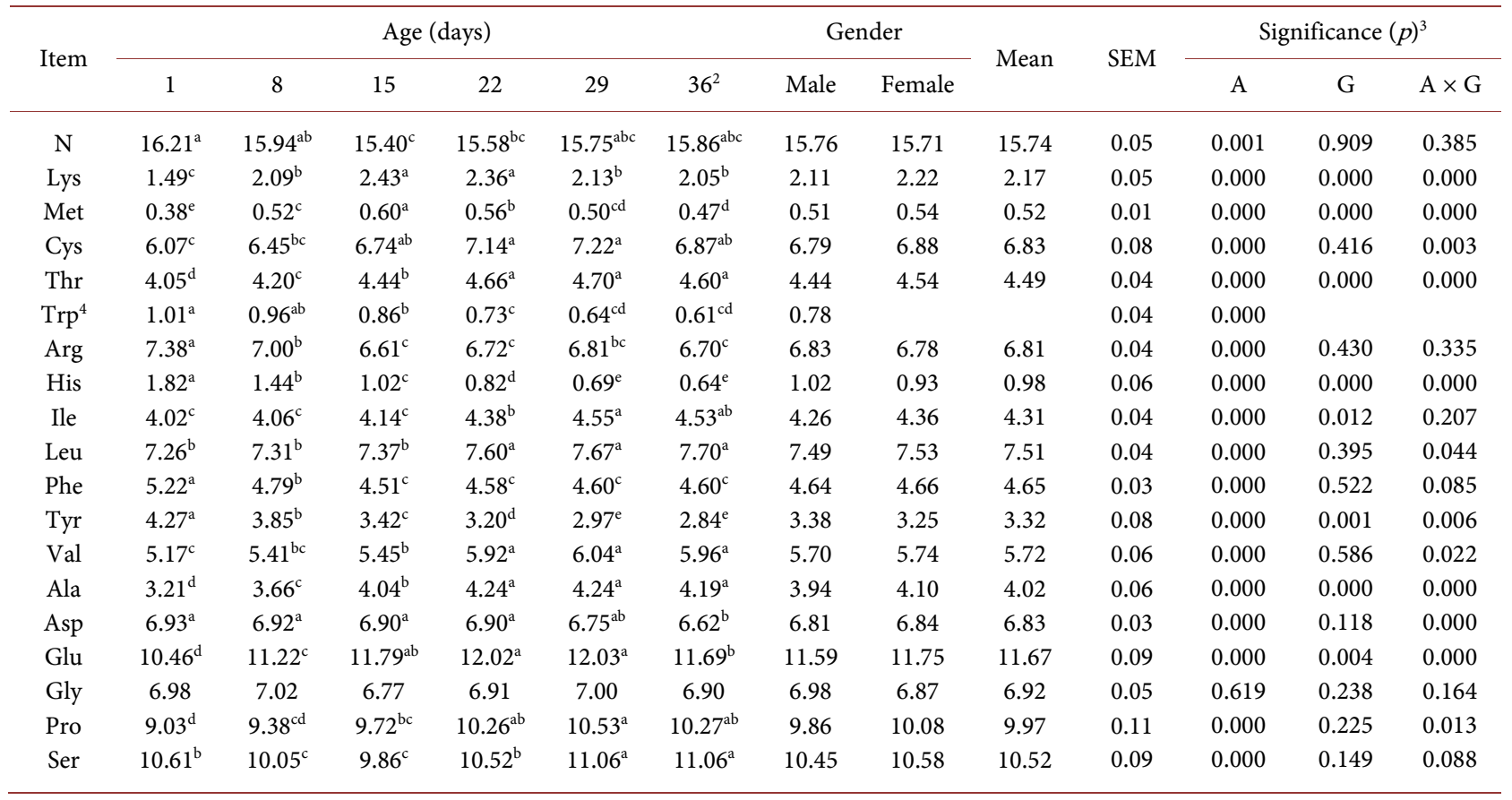

$\mathrm{N}=$ nitrogen, Lys = lysine, Met = methionine, Cys = cysteine, $\mathrm{Thr}=$ threonine, $\mathrm{Trp}=$ tryptophan, Arg = arginine, His = histidine, Ile $=$ isoleucine, Leu =

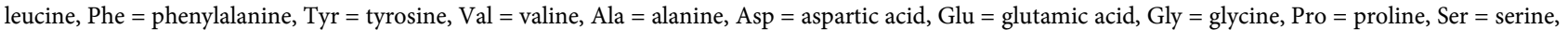
SEM = standard error of mean, $A=$ age, $G=$ gender, $A \times G=$ interaction between age and gender. ${ }^{1}$ At $1 \mathrm{~d}$ of age only two pooled feather samples (one per gender due to the low feather yield per bird), for remaining age periods $n=6$ pooled samples of each five birds ( 3 per gender) and $n=16$ pooled samples of each five birds per gender. ${ }^{2}$ Final body mass of male birds was determined at $35 \mathrm{~d}$ of age. ${ }^{3}$ Significance level $(p)$ of the two-way ANOVA. ${ }^{4}$ Due to technical reasons tryptophan was not determined in feathers of female birds. ${ }^{\text {abc }}$ Means of age-dependent data with different superscript letters within lines are significantly different $(p<0.05)$. 
threonine (Thr), isoleucine (Ile), Leu, valine (Val), alanine (Ala), Pro and Ser increased, but Trp, Arg, histidine (His), phenylalanine (Phe), tyrosine (Tyr) and aspartic acid (Asp) contents in the feather protein declined with increasing age of the birds. In addition, some gender-specific effects on AA composition of feathers were observed, but can hardly be explained.

The $\mathrm{N}$ content in the feather-free body DM of birds (Table 2) declined continuously with increasing of age $(p<0.001)$. Male birds contained significantly more $\mathrm{N}$ in the feather free body than female counterparts. As related to the AA composition of the feather protein, higher contents of Glu, Lys, His and Ala were present in the feather-free body protein. In contrast, lower quantities of Cys, Phe and Val were observed. Individual body AA composition was also age-dependent $(p<0.001)$. However, no significant age-dependent difference $(p>0.05)$ was observed for Ala and Asp in the feather-free body. Mostly, superior AA concentrations were found in the body protein of day-old chickens, but subsequently decreasing. In contrast, a progression in increase with increasing of age was obtained for Lys, Met, His, Ile and Glu. However, between $15 \mathrm{~d}$ to $36 \mathrm{~d}$ only trends were observed. Additionally, gender-specific effects $(p<0.05)$ on AA content of feather-free body protein were observed, except for Cys. Also for most of AAs significant interaction between age and gender could be detected.

A summary of the observed effects is illustrated in Figure 1. The columns are presented as means of AA concentrations in the feather protein as related to the

Table 2. Content of $\mathrm{N}$ (\% of dry matter) and amino acids ( $\mathrm{g} / 16 \mathrm{~g} \mathrm{~N}$ ) in the feather-free empty body of broiler chickens depending on age and gender. ${ }^{1}$

\begin{tabular}{|c|c|c|c|c|c|c|c|c|c|c|c|c|c|}
\hline \multirow{2}{*}{ Item } & \multicolumn{6}{|c|}{ Age (days) } & \multicolumn{2}{|c|}{ Gender } & \multirow{2}{*}{ Mean } & \multirow{2}{*}{ SEM } & \multicolumn{3}{|c|}{ Significance $(p)^{3}$} \\
\hline & 1 & 8 & 15 & 22 & 29 & $36^{2}$ & Male & Female & & & $\mathrm{A}$ & G & $A \times G$ \\
\hline $\mathrm{N}$ & $11.33^{\mathrm{a}}$ & $10.41^{\mathrm{b}}$ & $10.14^{\mathrm{bc}}$ & $10.07^{\mathrm{bcd}}$ & $9.78^{\mathrm{cd}}$ & $9.63^{\mathrm{d}}$ & 10.58 & 9.87 & 10.23 & 0.12 & 0.000 & 0.000 & 0.000 \\
\hline Lys & $6.51^{\mathrm{d}}$ & $6.75^{\mathrm{c}}$ & $6.83^{\mathrm{bc}}$ & $6.83^{\mathrm{bc}}$ & $7.03^{\mathrm{ab}}$ & $7.06^{\mathrm{a}}$ & 6.72 & 6.95 & 6.84 & 0.04 & 0.000 & 0.000 & 0.167 \\
\hline Met & $1.92^{\mathrm{c}}$ & $1.92^{\mathrm{c}}$ & $1.94^{\mathrm{c}}$ & $1.94^{\mathrm{bc}}$ & $2.00^{\mathrm{ab}}$ & $2.01^{\mathrm{a}}$ & 1.91 & 2.00 & 1.96 & 0.01 & 0.000 & 0.000 & 0.025 \\
\hline Cys & $1.07^{\mathrm{a}}$ & $1.00^{\mathrm{b}}$ & $0.95^{\mathrm{bc}}$ & $0.94^{c}$ & $0.92^{\mathrm{c}}$ & $0.94^{c}$ & 0.97 & 0.97 & 0.97 & 0.01 & 0.000 & 0.798 & 0.027 \\
\hline Thr & $4.04^{\mathrm{a}}$ & $3.89^{\mathrm{b}}$ & $3.84^{\mathrm{b}}$ & $3.84^{\mathrm{b}}$ & $3.88^{\mathrm{b}}$ & $3.81^{\mathrm{b}}$ & 3.80 & 3.96 & 3.88 & 0.02 & 0.000 & 0.000 & 0.004 \\
\hline $\operatorname{Trp}^{4}$ & $1.43^{\mathrm{a}}$ & $1.33^{\mathrm{b}}$ & $1.26^{\mathrm{c}}$ & $1.23^{\mathrm{cd}}$ & $1.28^{\mathrm{bc}}$ & $1.19^{\mathrm{d}}$ & 1.29 & & & 0.02 & 0.000 & & \\
\hline Arg & $6.53^{\mathrm{a}}$ & $6.25^{\mathrm{b}}$ & $6.06^{\mathrm{bc}}$ & $6.04^{\mathrm{c}}$ & $6.11^{\mathrm{bc}}$ & $6.09^{b c}$ & 6.10 & 6.26 & 6.18 & 0.04 & 0.000 & 0.000 & 0.007 \\
\hline His & $2.17^{\mathrm{e}}$ & $2.34^{\mathrm{d}}$ & $2.50^{\mathrm{c}}$ & $2.56^{\mathrm{bc}}$ & $2.65^{\mathrm{a}}$ & $2.62^{\mathrm{ab}}$ & 2.43 & 2.52 & 2.48 & 0.03 & 0.000 & 0.000 & 0.008 \\
\hline Ile & $3.61^{\mathrm{c}}$ & $3.72^{\mathrm{ab}}$ & $3.67^{\mathrm{bc}}$ & $3.71^{\mathrm{abc}}$ & $3.80^{\mathrm{a}}$ & $3.80^{\mathrm{a}}$ & 3.64 & 3.79 & 3.72 & 0.02 & 0.000 & 0.000 & 0.031 \\
\hline Leu & $7.04^{\mathrm{a}}$ & $6.84^{\mathrm{b}}$ & $6.78^{\mathrm{b}}$ & $6.79^{\mathrm{b}}$ & $6.89^{\mathrm{ab}}$ & $6.83^{\mathrm{b}}$ & 6.76 & 6.97 & 6.86 & 0.03 & 0.001 & 0.000 & 0.013 \\
\hline Phe & $3.85^{\mathrm{a}}$ & $3.70^{\mathrm{b}}$ & $3.60^{\mathrm{b}}$ & $3.61^{\mathrm{b}}$ & $3.64^{\mathrm{b}}$ & $3.62^{\mathrm{b}}$ & 3.61 & 3.73 & 3.67 & 0.02 & 0.000 & 0.000 & 0.024 \\
\hline Tyr & $3.17^{\mathrm{a}}$ & $2.95^{\mathrm{b}}$ & $2.87^{\mathrm{b}}$ & $2.86^{\mathrm{b}}$ & $2.91^{\mathrm{b}}$ & $2.88^{\mathrm{b}}$ & 2.90 & 2.98 & 2.94 & 0.02 & 0.000 & 0.000 & 0.316 \\
\hline Val & $4.06^{\mathrm{a}}$ & $3.92^{\mathrm{b}}$ & $3.78^{\mathrm{c}}$ & $3.83^{\mathrm{bc}}$ & $3.84^{\mathrm{bc}}$ & $3.79^{c}$ & 3.96 & 3.78 & 3.87 & 0.02 & 0.000 & 0.000 & 0.005 \\
\hline Ala & 6.00 & 5.84 & 5.91 & 5.93 & 5.98 & 5.93 & 5.89 & 5.97 & 5.93 & 0.02 & 0.103 & 0.032 & 0.003 \\
\hline Asp & 8.31 & 8.22 & 8.22 & 8.32 & 8.43 & 8.32 & 8.12 & 8.49 & 8.30 & 0.04 & 0.077 & 0.000 & 0.003 \\
\hline Glu & 14.52 & 14.49 & 14.48 & 14.55 & 14.88 & 14.85 & 14.09 & 15.17 & 14.63 & 0.10 & 0.016 & 0.000 & 0.262 \\
\hline Gly & $7.74^{\mathrm{a}}$ & $7.13^{\mathrm{b}}$ & $7.07^{\mathrm{b}}$ & $6.97^{\mathrm{bc}}$ & $6.91^{b c}$ & $6.76^{\mathrm{c}}$ & 7.19 & 7.01 & 7.10 & 0.06 & 0.000 & 0.003 & 0.012 \\
\hline Pro & $5.49^{\mathrm{a}}$ & $5.02^{\mathrm{b}}$ & $4.94^{\mathrm{bc}}$ & $4.91^{b c}$ & $4.71^{\mathrm{c}}$ & $4.82^{\mathrm{bc}}$ & 5.07 & 4.89 & 4.98 & 0.05 & 0.000 & 0.002 & 0.007 \\
\hline Ser & $4.40^{\mathrm{a}}$ & $3.92^{\mathrm{b}}$ & $3.80^{\mathrm{bc}}$ & $3.76^{\mathrm{cd}}$ & $3.75^{\mathrm{cd}}$ & $3.66^{\mathrm{d}}$ & 3.84 & 3.93 & 3.88 & 0.04 & 0.000 & 0.002 & 0.001 \\
\hline
\end{tabular}

Item (Abbreviations see Table 1), SEM = standard error of mean, $A=$ age, $\mathrm{G}=$ gender, $\mathrm{A} \times \mathrm{G}=$ interaction between age and gender. ${ }^{1}$ Per age period: $\mathrm{n}=6$ pooled samples ( 3 per gender) of each five birds; per gender: $n=18$ pooled samples of each five birds. ${ }^{2}$ Final body mass of male birds was determined at $35 \mathrm{~d}$ of age. ${ }^{3}$ Significance level $(p)$ of the two-way ANOVA. ${ }^{4}$ Due to technical reasons tryptophan was not determined in the body of female birds. ${ }^{\text {abc }}$ Means of age-dependent data with different superscript letters within lines are significantly different $(p<0.05)$. 


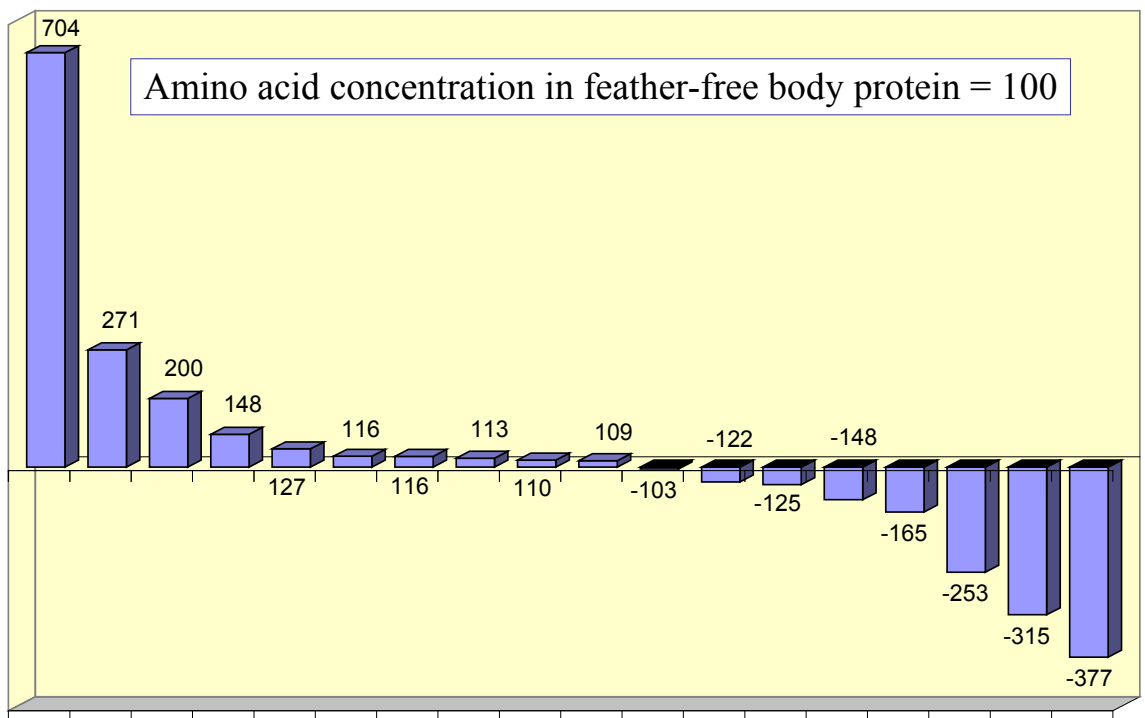

Cys Ser Pro Val Phe Ile Thr Tyr Arg Leu Gly Asp Glu Ala Trp His Lys Met

Figure 1. Relative deviation of the individual AA content in the protein of feather and feather-free body (Abbreviations see Table 1).

corresponding data in the feather-free body protein as reference. Accordingly, the mean Cys content in the feather protein fraction exceeded the Cys concentration in the feather-free body protein for more than seven times. In addition, markedly higher Ser, Pro and Val contents were obtained in feathers. In contrast, the feather protein contains approximately 3 to 4 times lower Lys and Met as well as 1.5 to 2.5 lower Ala, Trp and His than the feather-free body protein.

The $\mathrm{N}$ and AA composition of the whole empty body (Table 3 ) is quite similar to the feather-free body fraction due to the high protein partitioning of this fraction to the whole body protein [29]. If AA concentrations of both fractions (Table 2 vs. Table 3) are compared directly, a large divergence for Cys and Ser is obvious, but explained by their very high concentrations in the feather protein (Table 1, Figure 1). Generally, day-old and in parts $8 \mathrm{~d}$ old birds indicate significantly higher or lower AA concentrations $(p<0.05)$ than found in the body of older birds. No significant or extremely low differences were observed between remaining age periods ( $\geq 8 \mathrm{~d}$ ). As compared with male birds, the body of female birds contains significantly lower $\mathrm{N}$ but higher AA concentrations, except for Val, Gly and Pro. For most of body AA concentrations, significant interactions between age and gender were identified.

Table 4 summarizes the partitioning of individual AAs of the feather fraction expressed as percentage of the whole empty body AA content. As expected, a very high individual variation between AAs was observed, also depending on age $(p<0.001)$. Due to the high DM and protein content in feathers of $1 \mathrm{~d}$ old chickens [28] [29], the highest relative proportion of individual feather AAs was found in one day old birds, the lowest $(p<0.05)$ at $8 \mathrm{~d}$ or $15 \mathrm{~d}$ of age. Subsequently, the AA partition in the feather fraction increased continuously, except for His. 
Table 3. Content of $\mathrm{N}$ (\% of dry matter) and amino acids ( $\mathrm{g} / 16 \mathrm{~g} \mathrm{~N}$ ) in the whole empty body of broiler chickens depending on age and gender. ${ }^{1}$

\begin{tabular}{|c|c|c|c|c|c|c|c|c|c|c|c|c|c|}
\hline \multirow{2}{*}{ Item } & \multicolumn{6}{|c|}{ Age (days) } & \multicolumn{2}{|c|}{ Gender } & \multirow{2}{*}{ Mean } & \multirow{2}{*}{ SEM } & \multicolumn{3}{|c|}{ Significance $(p)^{3}$} \\
\hline & 1 & 8 & 15 & 22 & 29 & $36^{2}$ & Male & Female & & & $\mathrm{A}$ & G & $\mathrm{A} \times \mathrm{G}$ \\
\hline $\mathrm{N}$ & $11.83^{\mathrm{a}}$ & $10.67^{\mathrm{b}}$ & $10.37^{\mathrm{bc}}$ & $10.36^{\mathrm{bc}}$ & $10.12^{\mathrm{c}}$ & $10.06^{\mathrm{c}}$ & 10.89 & 10.24 & 10.57 & 0.12 & 0.000 & 0.000 & 0.066 \\
\hline Lys & $5.81^{\mathrm{b}}$ & $6.43^{\mathrm{a}}$ & $6.54^{\mathrm{a}}$ & $6.48^{\mathrm{a}}$ & $6.58^{\mathrm{a}}$ & $6.51^{\mathrm{a}}$ & 6.31 & 6.48 & 6.39 & 0.05 & 0.000 & 0.000 & 0.034 \\
\hline Met & $1.70^{\mathrm{b}}$ & $1.83^{\mathrm{a}}$ & $1.85^{\mathrm{a}}$ & $1.83^{\mathrm{a}}$ & $1.86^{\mathrm{a}}$ & $1.84^{\mathrm{a}}$ & 1.78 & 1.86 & 1.82 & 0.01 & 0.000 & 0.000 & 0.002 \\
\hline Cys & $1.77^{\mathrm{a}}$ & $1.38^{\mathrm{de}}$ & $1.33^{\mathrm{e}}$ & $1.42^{\mathrm{cd}}$ & $1.49^{c}$ & $1.58^{\mathrm{b}}$ & 1.46 & 1.53 & 1.49 & 0.03 & 0.000 & 0.000 & 0.000 \\
\hline Thr & $4.04^{\mathrm{a}}$ & $3.91^{\mathrm{b}}$ & $3.88^{\mathrm{b}}$ & $3.90^{\mathrm{b}}$ & $3.95^{\mathrm{ab}}$ & $3.89^{\mathrm{b}}$ & 3.85 & 4.01 & 3.93 & 0.02 & 0.001 & 0,000 & 0.002 \\
\hline $\operatorname{Trp}^{4}$ & $1.14^{\mathrm{bc}}$ & $1.31^{\mathrm{a}}$ & $1.24^{\mathrm{ab}}$ & $1.06^{\mathrm{c}}$ & $1.23^{\mathrm{ab}}$ & $1.14^{\mathrm{bc}}$ & 1.19 & & & 0.02 & 0.001 & & \\
\hline Arg & $6.65^{\mathrm{a}}$ & $6.30^{\mathrm{b}}$ & $6.09^{c}$ & $6.09^{c}$ & $6.18^{\mathrm{bc}}$ & $6.15^{\mathrm{bc}}$ & 6.17 & 6.32 & 6.24 & 0.04 & 0.000 & 0.000 & 0.005 \\
\hline His & $2.12^{\mathrm{d}}$ & $2.28^{\mathrm{c}}$ & $2.40^{\mathrm{b}}$ & $2.43^{\mathrm{ab}}$ & $2.47^{\mathrm{a}}$ & $2.41^{\mathrm{b}}$ & 2.33 & 2.38 & 2.35 & 0.02 & 0.000 & 0.000 & 0.001 \\
\hline Ile & $3.67^{\mathrm{b}}$ & $3.74^{\mathrm{b}}$ & $3.70^{\mathrm{b}}$ & $3.76^{\mathrm{b}}$ & $3.87^{\mathrm{a}}$ & $3.88^{\mathrm{a}}$ & 3.70 & 3.84 & 3.77 & 0.02 & 0.000 & 0.000 & 0.028 \\
\hline Leu & $7.08^{\mathrm{a}}$ & $6.88^{\mathrm{b}}$ & $6.82^{\mathrm{b}}$ & $6.85^{\mathrm{b}}$ & $6.96^{\mathrm{ab}}$ & $6.92^{\mathrm{b}}$ & 6.82 & 7.02 & 6.92 & 0.03 & 0.000 & 0.000 & 0.007 \\
\hline Phe & $4.04^{\mathrm{a}}$ & $3.77^{\mathrm{b}}$ & $3.66^{\mathrm{c}}$ & $3.69^{b c}$ & $3.73^{\mathrm{bc}}$ & $3.73^{b c}$ & 3.71 & 3.83 & 3.77 & 0.03 & 0.000 & 0.000 & 0.015 \\
\hline Tyr & $3.32^{\mathrm{a}}$ & $3.02^{\mathrm{b}}$ & $2.90^{c}$ & $2.89^{c}$ & $2.91^{\mathrm{c}}$ & $2.87^{\mathrm{c}}$ & 2.95 & 3.02 & 2.98 & 0.03 & 0.000 & 0.000 & 0.320 \\
\hline Val & $4.22^{\mathrm{a}}$ & $4.02^{\mathrm{b}}$ & $3.90^{c}$ & $3.99^{\mathrm{bc}}$ & $4.04^{\mathrm{b}}$ & $4.03^{\mathrm{b}}$ & 4.10 & 3.97 & 4.03 & 0.02 & 0.000 & 0.000 & 0.017 \\
\hline Ala & $5.61^{\mathrm{b}}$ & $5.69^{\mathrm{ab}}$ & $5.79^{\mathrm{a}}$ & $5.79^{\mathrm{a}}$ & $5.82^{\mathrm{a}}$ & $5.74^{\mathrm{ab}}$ & 5.71 & 5.77 & 5.74 & 0.02 & 0.006 & 0.043 & 0.000 \\
\hline Asp & 8.12 & 8.13 & 8.13 & 8.20 & 8.28 & 8.13 & 8.00 & 8.33 & 8.17 & 0.04 & 0.158 & 0,000 & 0.000 \\
\hline Glu & $13.96^{\mathrm{b}}$ & $14.26^{\mathrm{ab}}$ & $14.29^{\mathrm{ab}}$ & $14.35^{\mathrm{ab}}$ & $14.61^{\mathrm{a}}$ & $14.50^{\mathrm{a}}$ & 13.84 & 14.81 & 14.33 & 0.10 & 0.001 & 0.000 & 0.072 \\
\hline Gly & $7.64^{\mathrm{a}}$ & $7.13^{\mathrm{b}}$ & $7.04^{\mathrm{bc}}$ & $6.97^{\mathrm{bc}}$ & $6.92^{\mathrm{bc}}$ & $6.78^{c}$ & 7.17 & 6.99 & 7.08 & 0.06 & 0.000 & 0.002 & 0.009 \\
\hline Pro & $5.99^{\mathrm{a}}$ & $5.32^{\mathrm{b}}$ & $5.25^{\mathrm{b}}$ & $5.33^{\mathrm{b}}$ & $5.24^{\mathrm{b}}$ & $5.42^{\mathrm{b}}$ & 5.47 & 5.38 & 5.42 & 0.05 & 0.000 & 0.101 & 0.003 \\
\hline Ser & $5.27^{\mathrm{a}}$ & $4.34^{\mathrm{cd}}$ & $4.21^{\mathrm{e}}$ & $4.29^{\mathrm{de}}$ & $4.41^{b c}$ & $4.47^{\mathrm{b}}$ & 4.42 & 4.58 & 4.50 & 0.06 & 0.000 & 0.000 & 0.000 \\
\hline
\end{tabular}

Item (Abbreviations see Table 1), $\mathrm{SEM}=$ standard error of mean, $\mathrm{A}=$ age, $\mathrm{G}=$ gender, $\mathrm{A} \times \mathrm{G}=$ interaction between age and gender. ${ }^{1}$ Per age period: $\mathrm{n}=6$ pooled samples ( 3 per gender) of each five birds; per gender: $\mathrm{n}=18$ pooled samples of each five birds. ${ }^{2}$ Final body mass of male birds was determined at $35 \mathrm{~d}$ of age. ${ }^{3}$ Significance level $(p)$ of the two-way ANOVA. ${ }^{4}$ Due to technical reasons tryptophan was not determined in the body fractions of female birds. ${ }^{\mathrm{abc}}$ Means of age-dependent data with different superscript letters within lines are significantly different $(p<0.05)$.

Table 4. Percentage of feather amino acids as related to the whole empty body amino acid content of broiler chickens depending on age and gender. ${ }^{1}$

\begin{tabular}{|c|c|c|c|c|c|c|c|c|c|c|c|c|c|}
\hline \multirow{2}{*}{$\mathrm{AA}$} & \multicolumn{6}{|c|}{ Age (days) } & \multicolumn{2}{|c|}{ Gender } & \multirow{2}{*}{ Mean } & \multirow{2}{*}{ SEM } & \multicolumn{3}{|c|}{ Significance $(p)^{3}$} \\
\hline & 1 & 8 & 15 & 22 & 29 & $36^{2}$ & Male & Female & & & A & G & $A \times G$ \\
\hline Lys & $3.56^{\mathrm{a}}$ & $2.24^{\mathrm{c}}$ & $2.45^{\mathrm{bc}}$ & $2.84^{\mathrm{b}}$ & $2.93^{\mathrm{b}}$ & $3.43^{\mathrm{a}}$ & 2.65 & 3.17 & 2.91 & 0.10 & 0.000 & 0.000 & 0.008 \\
\hline Met & $3.08^{\mathrm{a}}$ & $1.96^{\mathrm{d}}$ & $2.13^{\mathrm{cd}}$ & $2.41^{\mathrm{bc}}$ & $2.41^{\mathrm{bc}}$ & $2.80^{\mathrm{ab}}$ & 2.25 & 2.68 & 2.46 & 0.09 & 0.000 & 0.000 & 0.006 \\
\hline Cys & $47.78^{\mathrm{a}}$ & $32.19^{c}$ & $33.19^{c}$ & $39.28^{\mathrm{b}}$ & $43.56^{\mathrm{ab}}$ & $47.05^{\mathrm{a}}$ & 38.43 & 42.58 & 40.51 & 1.21 & 0.000 & 0.000 & 0.002 \\
\hline Thr & $13.99^{\mathrm{a}}$ & $7.40^{\mathrm{b}}$ & $7.57^{\mathrm{c}}$ & $9.35^{\mathrm{b}}$ & $10.74^{\mathrm{b}}$ & $12.85^{\mathrm{a}}$ & 9.74 & 10.89 & 10.31 & 0.48 & 0.000 & 0.001 & 0.000 \\
\hline $\operatorname{Trp}^{4}$ & $13.62^{\mathrm{a}}$ & $4.98^{\mathrm{b}}$ & $3.70^{\mathrm{b}}$ & $5.00^{\mathrm{b}}$ & $4.09^{\mathrm{b}}$ & $5.05^{\mathrm{b}}$ & 6.07 & & & 0.84 & 0.000 & & \\
\hline Arg & $15.54^{\mathrm{a}}$ & $7.66^{\mathrm{d}}$ & $7.13^{\mathrm{d}}$ & $8.65^{\mathrm{cd}}$ & $9.97^{\mathrm{c}}$ & $11.83^{\mathrm{b}}$ & 9.67 & 10.58 & 10.13 & 0.54 & 0.000 & 0.007 & 0.000 \\
\hline His & $11.96^{\mathrm{a}}$ & $4.35^{\mathrm{b}}$ & $2.75^{\mathrm{c}}$ & $2.64^{\mathrm{c}}$ & $2.53^{\mathrm{c}}$ & $2.89^{c}$ & 4.62 & 4.42 & 4.52 & 0.58 & 0.000 & 0.376 & 0.002 \\
\hline Ile & $15.35^{\mathrm{a}}$ & $7.47^{\mathrm{d}}$ & $7.36^{\mathrm{d}}$ & $9.13^{c}$ & $10.61^{c}$ & $12.72^{\mathrm{b}}$ & 9.91 & 10.97 & 10.44 & 0.55 & 0.000 & 0.002 & 0.000 \\
\hline Leu & $14.36^{\mathrm{a}}$ & $7.32^{\mathrm{de}}$ & $7.11^{\mathrm{e}}$ & $8.69^{\mathrm{cd}}$ & $9.95^{c}$ & $12.09^{\mathrm{b}}$ & 9.44 & 10.40 & 9.92 & 0.50 & 0.000 & 0.002 & 0.000 \\
\hline Phe & $18.05^{\mathrm{a}}$ & $8.74^{\mathrm{d}}$ & $8.08^{\mathrm{d}}$ & $9.74^{\mathrm{cd}}$ & $11.16^{\mathrm{c}}$ & $13.46^{\mathrm{b}}$ & 11.00 & 12.07 & 11.54 & 0.63 & 0.000 & 0.007 & 0.000 \\
\hline Tyr & $17.95^{\mathrm{a}}$ & $8.80^{c}$ & $7.70^{c}$ & $8.67^{c}$ & $9.21^{\mathrm{bc}}$ & $10.76^{\mathrm{b}}$ & 10.22 & 10.81 & 10.51 & 0.63 & 0.000 & 0.098 & 0.000 \\
\hline Val & $17.12^{\mathrm{a}}$ & $9.27^{c}$ & $9.27^{\mathrm{c}}$ & $11.64^{\mathrm{b}}$ & $13.51^{\mathrm{b}}$ & $16.22^{\mathrm{a}}$ & 11.75 & 13.93 & 12.84 & 0.62 & 0.000 & 0.000 & 0.000 \\
\hline Ala & $7.99^{\mathrm{a}}$ & $4.43^{c}$ & $4.63^{c}$ & $5.74^{\mathrm{b}}$ & $6.59^{\mathrm{b}}$ & $7.95^{\mathrm{a}}$ & 5.72 & 6.72 & 6.22 & 0.29 & 0.000 & 0.000 & 0.000 \\
\hline Asp & $11.93^{\mathrm{a}}$ & $5.87^{\mathrm{d}}$ & $5.58^{\mathrm{d}}$ & $6.58^{\mathrm{cd}}$ & $7.36^{\mathrm{c}}$ & $8.86^{\mathrm{b}}$ & 7.36 & 8.03 & 7.70 & 0.41 & 0.000 & 0.009 & 0.000 \\
\hline Glu & $10.50^{\mathrm{a}}$ & $5.42^{\mathrm{d}}$ & $5.41^{\mathrm{d}}$ & $6.56^{\mathrm{cd}}$ & $7.42^{\mathrm{c}}$ & $8.75^{\mathrm{b}}$ & 7.08 & 7.61 & 7.34 & 0.35 & 0.000 & 0.022 & 0.000 \\
\hline Gly & $12.78^{\mathrm{a}}$ & $6.79^{\mathrm{d}}$ & $6.30^{\mathrm{d}}$ & $7.79^{\mathrm{cd}}$ & $9.16^{c}$ & $11.17^{\mathrm{b}}$ & 8.38 & 9.62 & 9.00 & 0.46 & 0.000 & 0.000 & 0.000 \\
\hline Pro & $21.03^{\mathrm{a}}$ & $12.15^{\mathrm{d}}$ & $12.18^{\mathrm{d}}$ & $15.11^{c}$ & $18.23^{\mathrm{b}}$ & $20.72^{\mathrm{a}}$ & 15.16 & 17.98 & 16.57 & 0.75 & 0.000 & 0.000 & 0.000 \\
\hline Ser & $28.10^{\mathrm{a}}$ & $15.93^{\mathrm{d}}$ & $15.48^{\mathrm{d}}$ & $19.20^{c}$ & $22.66^{\mathrm{b}}$ & $26.88^{\mathrm{a}}$ & 20.24 & 22.51 & 21.37 & 0.94 & 0.000 & 0.000 & 0.000 \\
\hline
\end{tabular}

$\mathrm{AA}=$ amino acid (Abbreviations see Table 1), $\mathrm{SEM}=$ standard error of mean, $\mathrm{A}=$ age, $\mathrm{G}=$ gender, $\mathrm{A} \times \mathrm{G}=$ interaction between age and gender. ${ }^{1}$ Per age period: $\mathrm{n}=6$ pooled samples ( 3 per gender) of each five birds; per gender: $\mathrm{n}=18$ pooled samples of each five birds. ${ }^{2}$ Final body mass of male birds was determined at $35 \mathrm{~d}$ of age. ${ }^{3}$ Significance level $(p)$ of the two-way ANOVA. ${ }^{4}$ Due to technical reasons tryptophan was not determined in the body fractions of female birds. ${ }^{\text {abc }}$ Means of age-dependent data with different superscript letters within lines are significantly different $(p<0.05)$. 
At $36 \mathrm{~d}$ of age, approximately 50 percent of feather AAs proportions came near to the initial level as observed in one day old chicken. With the exception of His and Tyr, also significant gender-specific effects of AA partitioning in the feather fraction were detected. In line with Figure 1, the highest relative proportions of feather AAs were demonstrated for Cys, Ser and Pro, the lowest proportions for Met, Lys and His.

\section{Discussion}

Our actual results have demonstrated that individual AA concentration in the feather and feather-free body protein of modern meat-type chicken is highly variable. This observation is in line with previous studies directly comparing the AA content of both body fractions [6] [7] [11] [13] [16] [18] [33] [34]. As summarized in Figure 1, important differences were observed for Cys, Ser and Pro with significantly higher and for Met, Lys and His with significantly lower content in the feather protein as compared to the feather-free body protein fraction. Likewise, considerable differences were found as the relative AA concentrations of both protein fractions were compared to the ideal dietary AA ratio with Lys as reference AA [35].

It is well-known that Cys is present in extremely high concentration in keratins [36]. In detail, this was reported for proteins from hair [37] [38] [39] [40], feathers [6] [7] [13] [14] [16] [18] [27] [33] [37] [40]-[45] and wool [37] [40]. In contrast, the remaining body protein fractions, predominantly the muscle and organ tissues of birds are rich in Lys [5] [6] [7] [11] [13] [15] [18] [44] [45] [46] [47]. Therefore, both the variation and displacement of the mostly important fractions like feather and carcass protein dependent on genotype, gender, age and nutrient supply may impact on the AA composition of the whole body protein of birds.

Nitsan et al. [33] reported that the AA content of feathers is quite consistent across most domesticated species. Stilborn et al. [16] found no significant effect on the feather AA content from two distinct broiler strain crosses and concluded later on that the carcass AA content, when expressed as percentage of protein, was also relatively constant despite genetic improvements [11]. The significantly higher Cys content in the accreted body protein of a laying bird as compared to a fast growing meat-type chicken [10] is not in contrast to these observations, but indicates a higher feather protein proportion [28]. Otherwise, no significant gender effect on feather AAs in growing chickens was reported [14] [16]. We observed marginal and negligible gender-specific effects in the feather protein (Table 1). According to Stilborn et al. [11], this conclusion also fits for all AAs in the feather-free body protein (Table 2). Higher AA contents were analysed in the feather-free body protein of female chickens, but corresponding with lower body protein as compared to their male counterparts [29]. Some small differences were abundant during the latter growth period reflecting different maturation rates between male and female birds [20]. 
Depending on age, the AA composition of the feather, feather-free body and whole body protein was assumed to be rather constant [1] [2] [3] [33]. However, according to our observations there are references for age-dependent effects on the content of individual AA both in the body and several body protein fractions of growing birds. In line with several reports [13] [14] [16] [18] [41] an age-dependent effect exists on individual feather AAs, indicating elevated Cys, Thr, Ile, Leu and Val but declined His, Trp and Tyr concentrations in the feather protein with increasing of age. Simultaneously, the content of nearly all dispensable AAs in feathers were also elevated with increasing age of the birds. In contrast, different trends were observed for Lys, Met, Arg and Phe. Additionally, it has to be pointed out that the feather AA data from freshly hatched day old chicken differ from other age periods. When these early data up to 1 week of age were excluded from data analysis, no or only marginal age-dependent differences for most of the individual feather AAs were observed. However, according to earlier reports [28] [29] the contribution of feathers to the whole body protein changes with age, mainly during early rapid growth.

But also feather structure and composition are age-dependent and individual morphological parts of fowl feathers show differences in AA composition [40] [48] [49] [50] [51]. In addition, also effects of diets deficient in branched chain AAs and methionine on AA content of the feather protein were reported [27] [43]. In case of deficient AA supply, feather protein synthesis is of superior priority [27] [52].

The observed variation of the AA content in the feather-free body protein was lower as compared to the feather protein. Apart from elevated Lys and His, but declined Cys, Trp, Val, Gly, Pro and Ser contents, the carcass AAs were rather constant when the data up to the end of the $1^{\text {st }}$ week were excluded. This statement agrees with several chicken and turkey studies [11] [13] [18] [44] [45]. Age and diet related changes of feather-free body AA composition could result from displacements between the muscle, bone and connective tissue proportions.

Looking on AA composition of the whole body protein (carcass plus feathers) of chickens, more data are available. Earlier investigations [1] [2] [3] indicate age-independent rather constant AA proportions. However, more recent reports also indicate some divergences for several AAs during first days of the growth period [3] [15] [45] or near to the market weight of meat-type chickens [3] [11]. These observations are in good agreement with our results (Table 3). Almost constant AA composition data are observed when both the $1^{\text {st }}$ week and last week ( $\mathrm{d}$ 36) data are excluded. Generally, the differences between $\mathrm{d} 8$ and $\mathrm{d} 36$ were negligible, except for Ile and Trp with advancing age. In contrast, superior content of Cys was found in day old chickens which declined within two weeks. Afterwards, an elevated Cys content was observed with increasing age. The age-dependent variation between individual AAs is explained by the increasing ratio of feather protein to whole body protein [3] [15] [24] [29] [53] [54] due to changes in feathering rate and resulting AA partitioning within body protein (Table 4). Altered proportions of different tissue proteins during growth [6] [10] 
[15] [20] [25] [33] [55] are additional factors. Muscle tissue is rich in Lys, bone and connective tissue is rich in Gly and Pro but low in Cys and Trp [40] [46] [56]. In consequence, elevated Lys content in the whole body protein indicates an elevated contribution of muscle tissue to the whole body [17]. Accordingly, lower contribution of bone and connective tissue results in lower contents of Gly, Pro and Trp in the featherless body protein with increasing of age.

In addition, both dietary energy and protein supply may contribute to modify whole body AA composition of broiler chickens, possibly by influencing the proportions of individual body tissues [15] [54]. Such observations are also reported dependent on dietary supply of Lys [9] [10] [22], Met or Met + Cys [25] [26] [27] [57], Thr [24], Trp [5] and Val [23] [43].

Finally has to be stated that published AA data of body protein fractions vary considerably, also attributed to different methodical procedures during sample preparation and chemical analysis [14] [46] [47] [58] [59]. Exemplarily, substantial Cys losses can be expected during autoclaving process of carcasses [47] [60]. In consequence, lower Cys contents were observed in feather meal following hydrothermal and pressure processing as compared to untreated feather protein [61] [62] [63]. Extended Cys degradation was also reported by commercial processing of feathers [39] [40] [64] [65] [66]. The current study dried and milled the feathers before analyses, but autoclaved the feather-free body samples [28]. This factor of pre-treatment needs attention when body AA composition data are compared.

Accordingly, literature data on AA content in the body of birds are diverse and the reference basis is not always clearly defined. Some data include the feather fraction whereas other data are related to the feather-free whole body. Sometimes there is no indication whether the so-called "carcass" fraction includes head, legs or internal organs. Furthermore, the exclusion of gastro-intestinal content in the analysis samples is a further factor limiting the comparability of reported data.

Despite this fact, Table 5 summarizes the AA composition of the feather, feather-free body and whole body protein as derived from the literature. Statistical analysis excluded single data which exceeded or remained below $30 \%$ of the calculated average for the individual AA. Regardless of the discussed factors of influence on individual AA content in body protein fractions, the averaged values fit our mean values as presented in Tables 1-3 very well. Minor divergences were within the range of the relatively high Min/Max variation (Table 5). Systematic differences were only found for $\mathrm{Val}$ and Glu, but are difficult to explain.

\section{Conclusions}

In fast growing meat-type chickens, the AA composition of the feather protein is not constant during the growth period up to market weight. However, minor gender dependent effects were observed for most of the AAs. According to different tissue growth and partitioning of the feather and remaining body protein 
Table 5. Amino acid content $(\mathrm{g} / 16 \mathrm{gN})$ in body fractions of growing chickens and observed variation from literature data ${ }^{1}$.

\begin{tabular}{|c|c|c|c|c|c|c|c|c|c|}
\hline \multirow{2}{*}{$\mathrm{AA}$} & \multicolumn{3}{|c|}{ Feather protein } & \multicolumn{3}{|c|}{ Feather-free protein } & \multicolumn{3}{|c|}{ Whole empty body protein } \\
\hline & $\mathrm{n}$ & Mean & Min/Max & $\mathrm{n}$ & Mean & $\operatorname{Min} / \operatorname{Max}$ & $\mathrm{n}$ & Mean & $\operatorname{Min} / \operatorname{Max}$ \\
\hline Lys & 12 & 2.0 & $1.6 / 2.5$ & 6 & 7.1 & $6.5 / 7.5$ & 16 & 6.4 & $5.7 / 7.5$ \\
\hline Met & 9 & 0.6 & $0.5 / 0.7$ & 3 & 2.2 & $1.8 / 2.5$ & 13 & 1.9 & $1.6 / 2.3$ \\
\hline Cys & 11 & 8.1 & $7.0 / 9.5$ & 3 & 1.1 & $1.0 / 1.3$ & 11 & 1.6 & $1.1 / 2.0$ \\
\hline Thr & 15 & 4.5 & $3.6 / 5.4$ & 7 & 4.0 & $3.2 / 4.5$ & 11 & 4.0 & $3.4 / 4.5$ \\
\hline $\operatorname{Trp}$ & 5 & 0.8 & $0.5 / 1.2$ & 4 & 1.0 & $0.8 / 1.5$ & 3 & 1.0 & $0.8 / 1.1$ \\
\hline Arg & 14 & 6.6 & $5.4 / 7.4$ & 6 & 7.0 & $6.6 / 7.9$ & 11 & 6.8 & $5.8 / 7.7$ \\
\hline His & 11 & 0.7 & $0.6 / 0.9$ & 6 & 2.4 & $2.0 / 3.0$ & 10 & 2.4 & $1.8 / 3.2$ \\
\hline Ile & 12 & 4.6 & $3.7 / 5.4$ & 5 & 4.0 & $3.9 / 4.2$ & 11 & 4.0 & $3.3 / 4.7$ \\
\hline Leu & 13 & 7.8 & $6.4 / 9.1$ & 5 & 7.3 & $6.6 / 7.7$ & 11 & 7.1 & $6.6 / 8.0$ \\
\hline Phe & 14 & 4.6 & $3.5 / 5.5$ & 6 & 4.2 & $3.9 / 5.0$ & 11 & 4.1 & $3.5 / 4.7$ \\
\hline Tyr & 13 & 2.7 & $2.2 / 3.4$ & 6 & 2.8 & $2.4 / 3.2$ & 9 & 2.9 & $2.5 / 3.1$ \\
\hline Val & 13 & 7.4 & $6.3 / 8.9$ & 6 & 5.4 & $4.8 / 6.7$ & 12 & 4.9 & $3.8 / 5.8$ \\
\hline Ala & 9 & 4.0 & $3.4 / 4.4$ & 4 & 6.4 & $5.5 / 6.9$ & 9 & 6.0 & $5.4 / 6.6$ \\
\hline Asp & 11 & 6.7 & $5.6 / 7.9$ & 4 & 8.7 & 7.1/9.4 & 9 & 8.4 & $7.8 / 9.2$ \\
\hline Glu & 11 & 9.4 & $7.9 / 11.3$ & 4 & 14.0 & $12.0 / 15.0$ & 10 & 12.9 & $11.8 / 13.9$ \\
\hline Gly & 11 & 6.8 & $5.7 / 9.1$ & 4 & 8.0 & $7.5 / 8.3$ & 8 & 7.9 & $6.6 / 9.2$ \\
\hline Pro & 9 & 9.2 & $7.5 / 10.9$ & 2 & 6.1 & $5.6 / 6.7$ & 9 & 6.3 & $5.1 / 7.3$ \\
\hline Ser & 9 & 11.0 & $8.9 / 11.6$ & 3 & 4.5 & $4.5 / 4.6$ & 9 & 4.5 & $3.6 / 4.9$ \\
\hline Ref. & \multicolumn{3}{|c|}{$\begin{array}{c}{[6][7][13][14][16][21][27]} \\
{[40][41][43][44][45][61]} \\
{[62][63]}\end{array}$} & & 7] [11] [ & ] [21] [44] & \multicolumn{3}{|c|}{$\begin{array}{c}{[1][2][3][4][5][9][10][15]} \\
{[23][24][25][26][27][57][67]}\end{array}$} \\
\hline
\end{tabular}

$\mathrm{AA}=\operatorname{amino}$ acid $($ Abbreviations see Table 1) $\mathrm{n}=$ Number of included literature values, Min/Max = range of averaged literature data (lowest/highest value), Ref. = references for AA data of the presented protein fraction. ${ }^{1}$ Only results between $1 \mathrm{~d}$ and $42 \mathrm{~d}$ of age were included.

fractions, the AA content in the feather-free body protein is varied considerably and responds on age-dependent empty body AA composition. These observations justify a separate evaluation of both fractions in factorial AA requirement studies because such important AAs like Lys and SAAs are involved and impacts on the derived ideal dietary AA ratio cannot be excluded.

The described procedure to derive AA body composition based on AAs in feathers and feather-free empty body yields reliable data for modelling of AA deposition in meat-type chickens providing an important precondition for valid evaluation of AA requirements based on factorial approaches.

\section{References}

[1] Price Jr., W.A., Taylor, M.W. and Russell, W.C. (1953) The Retention of Essential Amino Acids by the Growing Chick. The Journal of Nutrition, 51, 413-422. https://doi.org/10.1093/jn/51.3.413

[2] Williams, H.H., Curtin, L.V., Abraham, J., Loosli, J.K. and Maynard, L.A. (1954) Estimation of Growth Requirements for Amino Acids by Assay of the Carcass. Journal of Biological Chemistry, 208, 277-286.

[3] Holmes, W.B., Massey, D.M. and Owen, P.J. (1963) The Amino Acid Composition of Broiler Cockerels in Relation to Their Dietary Amino Acid Requirement. British Poultry Science, 4, 285-290. https://doi.org/10.1080/00071666308415507

[4] Saunders, A.J., Wessels, J.P.H. and Gous, R.M. (1977) Carcass Amino Acid Compo- 
sition and Utilization of Dietary Amino Acids by Chickens. South African Journal of Animal Science, 7, 111-115.

[5] Kirchgeßner, M., Steinhart, H. and Kreuzer, M. (1988) Amino Acid Pattern in the Carcass and Some Organs of Broiler Chicks Fed Different Amounts of Tryptophan and Neutral Amino Acids (In German). Archives of Animal Nutrition, 38, 905-919.

[6] Hurwitz, S., Sklan, D. and Bartov, I. (1978) New Formal Approaches of Energy and Amino Acid Requirements of Chicks. Poultry Science, 57, 197-205. https://doi.org/10.3382/ps.0570197

[7] GRRS (German Recommendations for Requirement Standards) Gesellschaft für Ernährungsphysiologie, Ausschuss für Bedarfsnormen (1999) Empfehlungen zur Energie- und Nährstoffversorgung der Legehennen und Masthühner (Broiler). DLG-Verlags-GmbH, Frankfurt am Main.

[8] Pesti, G.M., Leclercq, B., Chagneau, A.M. and Cochard, T. (1994) Comparative Responses of Genetically Lean and Fat Chickens to Lysine, Arginine and Non-Essential Amino Acid Supply. II. Plasma Amino Acid Responses. British Poultry Science, 35, 697-707. https://doi.org/10.1080/00071669408417736

[9] Edwards, H.M. III., Fernandez, S.R. and Baker, D.H. (1999) Maintenance Lysine Requirement and Efficiency of Using Lysine for Accretion of Whole-Body Lysine and Protein in Young Chicks. Poultry Science, 78, 1412-1417.

https://doi.org/10.1093/ps/78.10.1412

[10] Fatufe, A.A., Timmler, R. and Rodehutscord, M. (2004) Response to Lysine Intake in Composition of Body Weight Gain and Efficiency of Lysine Utilization of Growing Male Chickens from Two Genotypes. Poultry Science, 83, 1314-1324. https://doi.org/10.1093/ps/83.8.1314

[11] Stilborn, H.L., Moran, Jr., E.T., Gous, R.M. and Harrison, M.D. (2010) Influence of Age on Carcass (Feather-Free) Amino Acid Content for Two Broiler Strain-Crosses and Sexes. The Journal of Applied Poultry Research, 19, 13-23. https://doi.org/10.3382/japr.2009-00053

[12] Khan, D.R., Wecke, C. and Liebert, F. (2014) Amino Acid Composition of Body Protein in Naked Neck Meat Type Chickens Depending on Age, Gender and Genotype. Proceedings of the Society of Nutrition Physiology, 26, 128.

[13] Gruhn, K. and Anke, M. (1965) Crude Nutrient, Amino Acid and Mineral Content Variations in Fowl Developing from Day-Old Chicken to Young Hen. Archiv für Tierernährung, 15, 147-158. (In German) https://doi.org/10.1080/17450396509423119

[14] Fisher, M.-L., Leeson, S., Morrison, W.D. and Summers, J.D. (1981) Feather Growth and Feather Composition of Broiler Chickens. Canadian Journal of Animal Science, 61, 769-773. https://doi.org/10.4141/cjas81-093

[15] Kreuzer, M., Kirchgeßner, M. and Steinhart, H. (1988) Effect of the Level of Energy and Protein Supply, Respectively of Age on the Amino Acid Composition of Broiler Chicks. Archiv für Geflügelkunde, 52, 133-141. (In German)

[16] Stilborn, H.L., Moran, Jr., E.T., Gous, R.M. and Harrison, M.D. (1997) Effect of Age on Feather Amino Acid Content in Two Broiler Strain Crosses and Sexes. The Journal of Applied Poultry Research, 6, 205-209. https://doi.org/10.1093/japr/6.2.205

[17] Coon, C. (2004) The Ideal Amino Acid Requirements and Profile for Broilers, Layers, and Broiler Breeders. Technical Information of American Soybean Association, Brussels, FE 15, 1-43.

[18] Rivera-Torres, V., Noblet, J. and van Milgen, J. (2011) Changes in Chemical Com- 
position in Male Turkeys during Growth. Poultry Science, 90, 68-74. https://doi.org/10.3382/ps.2010-00633

[19] Martin, P.A., Bradford, G.D. and Gous, R.M. (1994) A Formal Method of Determining the Dietary Amino Acid Requirements of Laying-Type Pullets during Their Growing Period. British Poultry Science, 35, 709-724. https://doi.org/10.1080/00071669408417737

[20] Gous, R.M., Moran, Jr., E.T., Stilborn, H.R., Bradford, G.D. and Emmans, G.C. (1999) Evaluation of the Parameters Needed to Describe the Overall Growth, the Chemical Growth, and the Growth of Feathers and Breast Muscles of Broilers. Poultry Science, 78, 812-821. https://doi.org/10.1093/ps/78.6.812

[21] Bonato, M.A., Sakomura, N.K., Gous, R.M., Rafael, J.M. and Bendezu, H.C.P. (2013) The Response to Dietary Threonine in Growing Pullets. 19th European Symposium on Poultry Nutrition, Potsdam, File 0051, 1-5.

[22] Couch, J.R., Trammell, J.H., Cooper, J., Farr, F.M. and Abbott, W.W. (1972) The Effect of Feeding a Sub-Optimum Level of Lysine to Female Chicks on the Amino Acid Content of Selected Tissues and Organs. British Poultry Science, 13, 425-434. https://doi.org/10.1080/00071667208415970

[23] Baker, D.H., Fernandez, S.R., Parsons, C.M., Edwards, H.M., III, Emmert, J.L. and Webel, D.M. (1996) Maintenance Requirement for Valine and Efficiency of Its Use Above Maintenance for Accretion of Whole Body Valine and Protein in Young Chicks. The Journal of Nutrition, 126, 1844-1851.

[24] Edwards, H.M., III, Baker, D.H., Fernandez, S.R. and Parsons, C.M. (1997) Maintenance Threonine Requirement and Efficiency of Its Use for Accretion of Whole-Body Threonine and Protein in Young Chicks. British Journal of Nutrition, 78, 111-119. https://doi.org/10.1079/BJN19970123

[25] Fatufe, A.A. and Rodehutscord, M. (2005) Growth and Body Composition, and Marginal Efficiency of Methionine Utilization Are Affected by Nonessential Amino Acid Nitrogen Supplementation in Male Chicken. Poultry Science, 84, 1584-1592. https://doi.org/10.1093/ps/84.10.1584

[26] Conde-Aguilera, J.A., Cobo-Ortega, C., Tesseraud, S., Lessire, M., Mercier, Y. and van Milgen, J. (2013) Changes in Body Composition in Broilers by a Sulphur Amino Acid Deficiency during Growth. Poultry Science, 92, 1266-1275.

https://doi.org/10.3382/ps.2012-02796

[27] Conde-Aguilera, J.A., Cholet, J.C.G., Lessire, M., Mercier, Y., Tesseraud, S. and van Milgen, J. (2016) The Level and Source of Free-Methionine Affect Body Composition and Breast Muscle Traits in Growing Broilers. Poultry Science, 95, 2322-2331. https://doi.org/10.3382/ps/pew105

[28] Wecke, C., Khan, D.R., Sünder, A. and Liebert, F. (2017) Age and Gender Depending Growth of Feathers and Feather-Free Body in Modern Fast Growing Meat-Type Chickens. Open Journal of Animal Sciences, 7, 376-392. https://doi.org/10.4236/ojas.2017.74029

[29] Wecke, C., Khan, D.R., Sünder, A. and Liebert, F. (2018) Age and Gender Dependent Nutrient Composition of Feather and Feather-Free Body Fractions in Meat-Type Chickens. Open Journal of Animal Sciences, 8, 74-86. https://doi.org/10.4236/ojas.2018.81006

[30] Wecke, C. and Liebert, F. (2013) Improving the Reliability of Optimal In-Feed Amino Acid Ratios Based on Individual Amino Acid Efficiency Data from N Balance Studies in Growing Chicken. Animals, 3, 558-573. https://doi.org/10.3390/ani3030558 
[31] Naumann, C. and Bassler, R. (1976-2004) The Chemical Analysis of Feedstuffs. Methodenbuch, Vol. III, VDLUFA-Verlag, Darmstadt. (In German)

[32] The Commission of the European Communities (2009) Commission Regulation (EC) No 152/2009 of 27 January 2009 Laying down the Methods of Sampling and Analysis for the Official Control of Feed. Official Journal of the European Union, L54/1-L54/130.

[33] Nitsan, Z., Dvorin, A. and Nir, I. (1981) Composition and Amino Acid Content of Carcass, Skin and Feathers of the Growing Gosling. British Poultry Science, 22, 79-84. https://doi.org/10.1080/00071688108447866

[34] Wecke, C. and Liebert, F. (2016) Nitrogen Content and Sulfur Containing Amino Acid Concentration in Feather and Feather-Free Body Protein of Fast Growing Meat Type Broiler Chicken Dependent on Gender and Age. Proceedings of the Society of Nutrition Physiology, 25, 29.

[35] Wecke, C., Sünder, A. and Liebert, F. (2018) Amino Acid Ratios in Feather, Feather-Free and Whole Body Protein of Meat-Type Chickens as Related to the Recommended Ideal Dietary Amino Acid Ratio. Proceedings of the Society of $\mathrm{Nu}$ trition Physiology, 27, 55.

[36] Block, R.J. (1939) The Composition of Keratins. The Amino Acid Composition of Hair, Wool, Horn, and Other Eukeratins. Journal of Biological Chemistry, 128, 181-186.

[37] Graham, C.E., Waitkoff, H.K. and Hier, S.W. (1949) The Amino Acid Content of Some Scleroproteins. Journal of Biological Chemistry, 177, 529-532.

[38] Baker, D.H., Becker, D.E., Norton, H.W., Jensen, A.H. and Harmon, B.G. (1966) Quantitative Evaluation of the Tryptophan, Methionine and Lysine Needs of Adult Swine for Maintenance. Journal of Nutrition, 89, 441-447. https://doi.org/10.1093/jn/89.4.441

[39] Moran, Jr., E.T., Bayley, H.S. and Summers, J.D. (1967) Keratin as Source of Protein for the Growing Chick. 3. The Metabolizable Energy and Amino Acid Composition of Raw and Processed Hog Hair Meal with Emphasis on Cystine Destruction with Autoclaving. Poultry Science, 46, 548-553. https://doi.org/10.3382/ps.0460548

[40] Kling, M. and Wöhlbier, W. (1977) Commercial Feedstuffs. Vol. 1, Verlag Eugen Ulmer Stuttgart. (In German)

[41] Strohschneider, R. (1981) Feed Protein and Amino Acid Utilization in Growing Chickens Depending on Dietary Protein Content. PhD Thesis, Georg-August-Universität Göttingen, Göttingen, 135. (In German)

[42] Murphy, M.E. and King, J.R. (1982) Amino Acid Composition of the Plumage of the White-Crowned Sparrow. Condor, 84, 435-438. https://doi.org/10.2307/1367449

[43] Farran, M.T. and Thomas, O.P. (1992) Valine Deficiency. 1. The Effect of Feeding a Valine-Deficient Diet during the Starter Period on Performance and Feather Structure of Male Broiler Chicks. Poultry Science, 71, 1879-1884. https://doi.org/10.3382/ps.0711879

[44] Sklan, D. and Noy, Y. (2004) Catabolism and Deposition of Amino Acids in Growing Chicks: Effect of Dietary Supply. Poultry Science, 83, 952-961. https://doi.org/10.1093/ps/83.6.952

[45] Sklan, D. and Noy, Y. (2005) Direct Determination of Optimal Amino Acid Intake for Maintenance and Growth in Broilers. Poultry Science, 84, 412-418. https://doi.org/10.1093/ps/84.3.412

[46] Hamm, D. (1981) Amino Acid Composition of Breast and Thigh Meat from Broil- 
ers Produced in Four Locations of the United States. Journal of Food Science, 46, 1122-1124. (In German) https://doi.org/10.1111/j.1365-2621.1981.tb03005.x

[47] Brede, A., Wecke, C., Sünder, A. and Liebert, F. (2018) Characteristics of Sulfur Containing Amino Acid Supply with Special Reference to Poultry Nutrition. Übersichten zur Tierernährung, 43, In Press. (In German)

[48] Harrap, B.S. and Woods, E.F. (1964) Soluble Derivatives of Feather Keratin. 1. Isolation, Fractionation and Amino Acid Composition. Biochemical Journal, 92, 8-18. https://doi.org/10.1042/bj0920008

[49] Harrap, B.S. and Woods, E.F. (1967) Species Differences in the Proteins of Feathers. Comparative Biochemistry and Physiology, 20, 449-460. https://doi.org/10.1016/0010-406X(67)90260-5

[50] Kemp, D.J. and Rogers, G.E. (1972) Differentiation of Avian Keratinocytes. Characterization and Relationships of the Keratin Proteins of Adult and Embryonic Feathers and Scales. Biochemistry, 11, 969-975. https://doi.org/10.1021/bi00756a005

[51] Akahane, K., Murozono, S. and Murayama, K. (1977) Soluble Proteins from Fowl Feather Keratin. I. Fractionation and Properties. The Journal of Biochemistry, 81, 11-18. https://doi.org/10.1093/oxfordjournals.jbchem.a131425

[52] Wylie, L.M., Robertson, G.W., MacLeod, M.G. and Hocking, P.W. (2001) Effects of Ambient Temperature and Restricted Feeding on the Growth of Feathers in Growing Turkeys. British Poultry Science, 42, 449-455. https://doi.org/10.1080/00071660120070631

[53] Fisher, C. and Scougall, R.K. (1982) A Note on the Amino Acid Composition of the Turkey. British Poultry Science, 23, 33-237. https://doi.org/10.1080/00071688208447951

[54] Kirchgeßner, M., Kreuzer, M. and Steinhart, H. (1987) Effects of Different Energy and Protein Contents in the Rations on the Amino Acid Retention of Broiler Chicks. Landwirtschaftliche Forschung, 40, 181-195. (In German)

[55] Bonato, M.A., Sakomura, N.K., Gous, R.M., Silva, E.P., Soares, L. and Peruzzi, N.J. (2016) Description of a Model to Optimise the Feeding of Amino Acids to Growing Pullets. British Poultry Science, 57, 123-133. https://doi.org/10.1080/00071668.2015.1127892

[56] Mello, F.C., Jr., Field, R.A. and Chang, Y.O. (1975) Amino Acid Profile of Bovine Bone during Growth. Growth, 39, 241-249.

[57] Edwards III, H.M. and Baker, D.H. (1999) Maintenance Sulfur Amino Acid Requirements of Young Chicks and Efficiency of Their Use for Accretion of Whole-Body Sulfur Amino Acids and Protein. Poultry Science, 78, 1418-1423. https://doi.org/10.1093/ps/78.10.1418

[58] Dennison, C. and Gous, R.M. (1984) Hydrolysis Conditions for the Analysis for Sulfur Amino Acids in Feedstuffs. South African Journal of Animal Science, 14, 64-69.

[59] Latshaw, J.D. (1990) Quality of Feather Meal as Affected by Feather Processing Conditions. Poultry Science, 69, 953-958. https://doi.org/10.3382/ps.0690953

[60] Sünder, A., Höhling, A. and Liebert, F. (2015) Amino Acid Composition of Novel Protein Sources from Thermal Hydrolysis of Pig and Poultry By-Products. Proceedings of the Society of Nutrition Physiology, 24, 48.

[61] McCasland, W.E. and Richardson, L.R. (1966) Methods for Determining the Nutritive Value of Feather Meals. Poultry Science, 45, 1231-1236.

https://doi.org/10.3382/ps.0451231 
[62] Papadopoulos, M.C., El Boushy, A.R., Roodbeen, A.R. and Ketelaars, E.H. (1986) Effects of Processing Time and Moisture Content on Amino Acid Composition and Nitrogen Characteristics of Feather Meal. Animal Feed Science and Technology, 14, 279-290. https://doi.org/10.1016/0377-8401(86)90100-8

[63] Kormanjos, S., Kostadinovic, L., Popovic, S., Njezic, Z., Radovic, V. and Puvaca, N. (2015) Influence of Feathers Hydrothermal Processing on Bioactive Substances in Obtained Feather Meal. Annals of Biological Research, 6, 6-11.

[64] Papadopoulos, M.C., El Boushy, A.R. and Ketelaars, E.H. (1985) Effect of Different Processing Conditions on Amino Acid Digestibility of Feather Meal Determined by Chicken Assay. Poultry Science, 64, 1729-1741. https://doi.org/10.3382/ps.0641729

[65] Wang, X. and Parsons, C.M. (1997) Effect of Processing Systems on Protein Quality of Feather Meals and Hog Hair Meals. Poultry Science, 76, 491-496. https://doi.org/10.1093/ps/76.3.491

[66] Moritz, J.S. and Latshaw, J.D. (2001) Indicators of Nutritional Value of Hydrolyzed Feather Meal. Poultry Science, 80, 79-86. https://doi.org/10.1093/ps/80.1.79

[67] Lepore, P.D., Siegel, P.B. and King, K.W. (1963) Proximate and Amino Acid Composition of Eggs and Chicks from Growth-Selected Lines of White Rocks. Life Sciences, 2, 584-593. https://doi.org/10.1016/0024-3205(63)90111-5 